1974

\title{
Excavation of 41FY58, Fayette County, Texas
}

John E. Keller

Follow this and additional works at: https://scholarworks.sfasu.edu/ita

Part of the American Material Culture Commons, Archaeological Anthropology Commons, Environmental Studies Commons, Other American Studies Commons, Other Arts and Humanities Commons, Other History of Art, Architecture, and Archaeology Commons, and the United States History Commons

Tell us how this article helped you.

This Article is brought to you for free and open access by the Center for Regional Heritage Research at SFA ScholarWorks. It has been accepted for inclusion in Index of Texas Archaeology: Open Access Gray Literature from the Lone Star State by an authorized editor of SFA ScholarWorks. For more information, please contact cdsscholarworks@sfasu.edu. 


\section{Excavation of 41FY58, Fayette County, Texas}

\section{Licensing Statement}

This is a work for hire produced for the Texas Department of Transportation (TxDOT), which owns all rights, title, and interest in and to all data and other information developed for this project under its contract with the report producer. The report may be cited and brief passages from this publication may be reproduced without permission provided that credit is given to TXDOT and the firm that produced it. Permission to reprint an entire chapter, section, figures or tables must be obtained in advance from the Supervisor of the Archeological Studies Branch, Environmental Affairs Division, Texas Department of Transportation, 125 East 11th Street, Austin, Texas, 78701 


\title{
EXCAVATION OF 41 FY 58 \\ FAYETTE COUNTY, \\ TEXAS
}

\author{
By \\ John E. K eller
}

Texas Highway Department Publications in Archaeology

Division of Highway Design

August, 1974 


\section{Excavation of 41 FY 58, Fayette County, Texas}

by John E. Keller

The site 41 FY 58 was discovered on U.S. 71 in eastern Fayette County and reported in 1973 by the survey archaeologist of the Texas Highway Department. Surface indications were highly encouraging and the site was recommended for extensive investigation.

The site is located on a gravel terrace above the extensive floodplain of the Colorado River. The site faces south just above a small spring emitting from the terrace gravels. Expectations were excellent,

Under Antiquities Committee Permit for Archaeological Investigation No. 59, excavation began on July 12 and continued to July 16, 1974. During this time it became apparent that the site was far less extensive than originally believed and in a highly disturbed condition. Disappointment was enhanced by a very shallow depth of deposit. On the average, cultural material was concentrated in the upper 6" and never exceeded one foot in depth. Below that level, the covering topsoil merged into underlying gravel beds. These gravels probably served as the source of suit - . able lithic materials but precluded the development of stratified positions and greatly hampered excavation.

Cultural material appeared concentrated in only one small portion of the knoll. This area of concentration had been cultivated for a number of years as a garden being the only sandy 
area on the site and was in a highly disturbed state. Material had been collected from the site for a number of years and as a result, diagnostic artifacts were present in only small numbers. Screening through $1 / 4$ inch mesh resulted in recovery of the cultural material most of which was thermally fractured. Only two diagnostic projectile point types were recovered: a Pedernales point from the surface and one Darl base from excavation. Nine $5^{\prime} x 5^{\prime}$ units were excavated.

These materials in combination with those collected by local amateurs at the site presented the appearance of a primarily late settlement. Other materials known to have come from the site included large crudely worked bifaces, retouched flakes, one large pressure flaked biface with beveled edges, and a number of finely worked unifaces.

It appears likely that the large amount of flakes and flaking debris resulted from some sort of workshop activity. The local gravel deposits would support extensive lithic activity. Test excavations at two other site $41 \mathrm{FY} 57$, and $41 \mathrm{FY} 61 \mathrm{disclosed}$ similar occurrences and may in fact delineate a fairly common pattern in that sites on gravel terraces in Fayette County tend to have little depth and are primarily of a workshop nature.

Because of its location, it was felt that Paleo Indian artifacts might be found. Such was not the case.

In conclusion, the site proved to be a disappointment. 


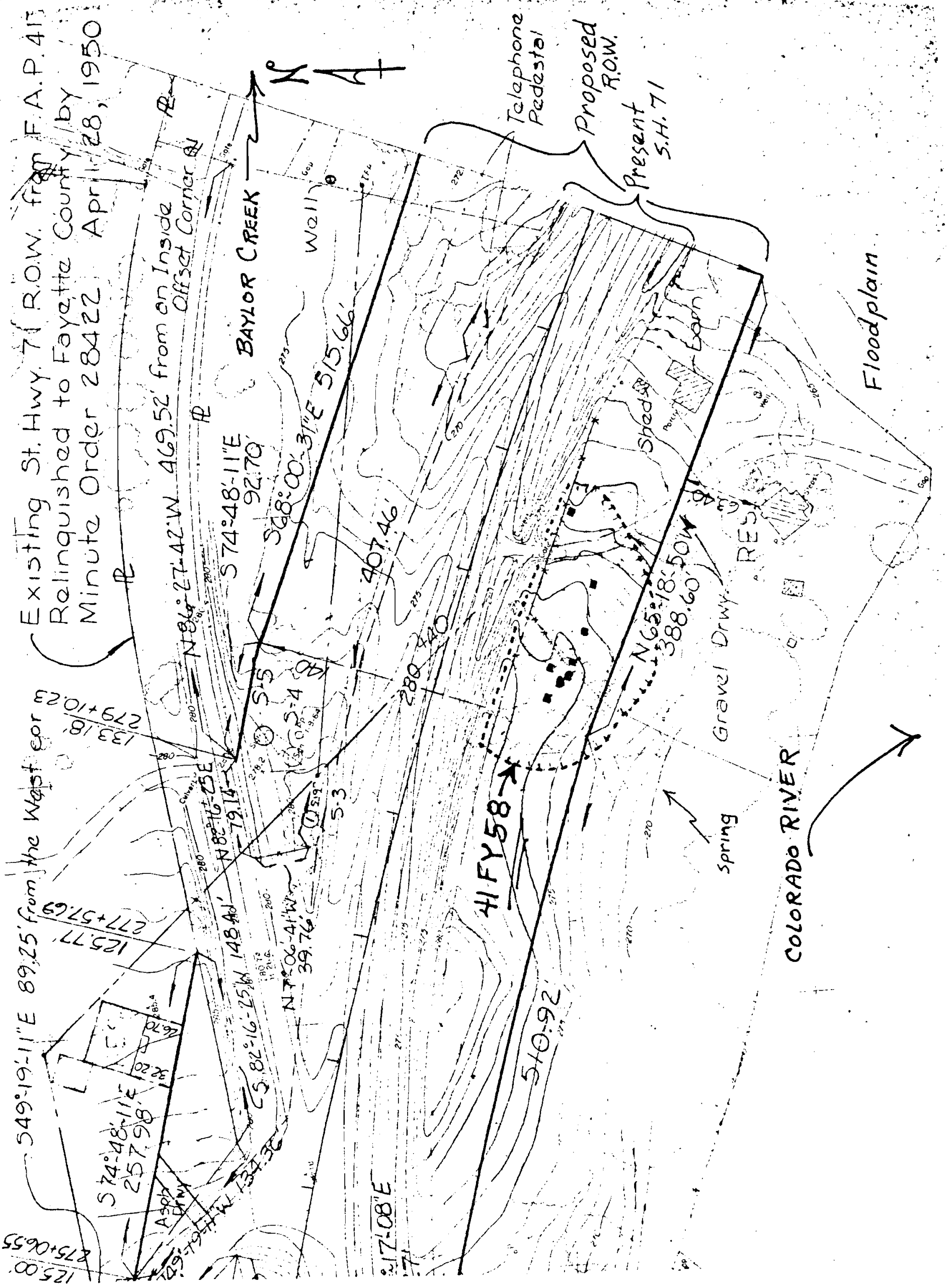

